
\title{
on the Performance and Meat Quality of Broiler Chickens
}

\section{author(s) \\ Ren LI,II \\ Zuo J' \\ Li G' \\ Zheng L' \\ Zhang Z' \\ Ye $\mathrm{H}^{\prime}$ \\ Xia $W^{\prime}$ \\ Feng $D^{\prime}$}

College of Animal Science and Technology, South China Agriculture University, Guangzhou 510642,China

" College of Agriculture, Guangdong Ocean University, Zhanjiang 524000, China

Project funded by Nature Science Foundation of China

\section{-Mail Address}

Corresponding author e-mail address Prof. D. Y. Feng

College of Animal Science and Technology, South China Agricultural University, Room

1406, Building D, Xingfayuan, South Habin Road, Xiashan District, Zhanjiang city Guangzhou, 510642, China.

Phone: (+86) 13531102669

E-mail: fengdy@scau.edu.cn renlils2004@163.com

\section{Eeywords}

Broiler, non-phytatephosphorus, performance, phytase, 25-hydroxycholecalciferol.

\section{ABSTRACT}

This experiment was conducted to evaluate the combination effect of low dietary non-phytate phosphorus (NPP) concentrations, phytase (PHY) levels, and 25-hydroxycholecalciferol $\left(25-\mathrm{OH}-\mathrm{D}_{3}\right)$ levels on the growth performance and meat quality of broilers. Two levels of NPP, two levels of PHY, and two levels of $25-\mathrm{OH}-\mathrm{D}_{3}$ resulted in a $2 \times 2 \times 2$ factorial arrangements, with eight treatments (TRT). The birds on TRT 1-4 were fed diet 1 (NRC NPP was reduced by 0.1) and the birds on TRT 5-8 were fed with diet 2 (NRC NPP was reduced by 0.2). Each diet was mixed with different levels PHY and $25-\mathrm{OH}-\mathrm{D}_{3}$. Performance and meat quality parameters were measured. Results showed that during entire experiment the most advantageous effects were obtained with TRT 3 (NRC NPP reduced by $0.1+600 \mathrm{U} / \mathrm{kg}$ phytase $+34.5 \mu \mathrm{g} / \mathrm{kg} 25-\mathrm{OH}-\mathrm{D}_{3}$ ) and TRT 4 (NRC NPP reduced by $0.1+600 \mathrm{U} / \mathrm{kg}$ phytase $+69 \mu \mathrm{g} / \mathrm{kg} 25-$ $\mathrm{OH}-\mathrm{D}_{3}$ ). The lowest body weight gain (BWG) and feed intake(FI) were observed with TRT 5 (NRC NPP reduced by $0.2+300 \mathrm{U} / \mathrm{kg}$ phytase $+34.5 \mu \mathrm{g} / \mathrm{kg} 25-\mathrm{OH}-\mathrm{D}_{3}$ ). Lowering NRC NPP by 0.1 to 0.2 significantly reduced weight gain $(\mathrm{WG})(\mathrm{p}<0.05)$ and $\mathrm{Fl}(\mathrm{p}<0.05)$ during the starter phase (ST), while during grower phase (GF) lowering NRC NPP by 0.1 to 0.2 did not affect WG ( $p>0.05)$ and produced small decrease in FI. BWG, $\mathrm{FI}$ and feed conversion ratio were not influenced ( $p>0.05$ ) by different $\mathrm{PHY}$ or $25-\mathrm{OH}-\mathrm{D}_{3}$ levels. In addition, the meat color, $\mathrm{pH}$, and shear force were not affected by the different NPP, PHY or $25-\mathrm{OH}-\mathrm{D}_{3}$ levels.

\section{INTRODUCTION}

Phosphorus (P) pollution from animal waste has become a major environmental concern in recent years. Reducing dietary phosphorus is an effective method to minimize phosphorus pollution (Angel et al., 2006; Powell et al., 2008; Rama Rao et al., 2009; Pillai et al., 2009). Recent studies showed that the National Research Council (NRC,1994) recommendations of non-phytate phosphorus (NPP) exceed the requirements of modern broiler chickens (Angel et al., 2000a,b; Yan et al., 2001 and Angel et al., 2005). It should be an important economic and environmental concern to formulate diets to precisely meet the phosphorus requirements of poultry (Summers, 1997).

Another method to reduce phosphorus pollution is to use feed additives, such as microbial phytase (PHY), to increase the utilization of dietary phosphorus. Microbial phytases have been widely used in animal diets to increase phytate $\mathrm{P}(\mathrm{PP})$ availability and to reduce inorganic $\mathrm{P}$ supplementation (Lalpanmawia et al., 2014) and P excretion (Pillai et al., 2009; Naves et al., 2014). Furthermore, several studies indicated that vitamin $\mathrm{D}_{3}$ metabolites, such as 1,25-dihydroxycholecalciferol $\left(1,25-(\mathrm{OH})_{2}-\mathrm{D}_{3}\right), \quad 25$-hydroxycholecalciferol $\quad\left(25-\mathrm{OH}-\mathrm{D}_{3}\right)$, and $1 \alpha$-hydroxycholecalciferol $\left(1 \alpha-\mathrm{OH}-\mathrm{D}_{3}\right)$, can enhance phytate phosphorus 
utilization (Biehl et al., 1995; Janocha 2et al., 2009 and Tatara et al., 2011). The $25-\mathrm{OH}-\mathrm{D}_{3}$ has been successfully developed into a new feed additives to the industry today. Previous reports (Angel et al., 2005; Driver et al., 2005; Coto et al., 2008; Liem et al., 2009) suggested that cholecalciferol analog might work either alone or in combination with phytase to markedly improve utilization of dietary P. However, the combination effect of lower dietary NPP levels, PHY levels and $25-\mathrm{OH}-\mathrm{D}_{3}$ levels has not been evaluated.

Supplementation of vitamin $D_{3}$ affects meat quality (Montgomery et al., 2004; Moron et al., 2008). Han et al. (2009) reported that $1 \alpha-O H-D_{3}$ increase lightness and yellowness of the breast and thigh meat whereas it decrease the shear force and water-holding capacity of the thigh meat.

Our objective was to evaluate the combination effect of lower dietary NPP levels, PHY levels and 25$\mathrm{OH}-\mathrm{D}_{3}$ levels on the growth performance and meat quality of the broilers.

\section{MATERIALS AND METHODS}

\section{Birds, Diets, Feeding, and Management}

The procedures of this experiment were approved by the Animal Care and Use Committee of the South China Agriculture University.

The experiment was conducted in a broiler house for $42 \mathrm{~d}$ during the fall. Two thousand and four hundred one-day-old yellow-feathered male broilers were randomly assigned to eight treatments according to the randomized complete block design, with five replicates per treatment. Birds were weighed and allocated to treatment groups in order to obtain similar initial average body weights among the treatment groups. The pens were located in a well-ventilated open sided house with pine-shavings. Birds were submitted to $24 \mathrm{~h}$ of light and same management practices. Each pen $(260 \times 320 \mathrm{~cm})$ was considered a replicate. The temperature inside the pen was maintained at $33^{\circ} \mathrm{C}$ on day 1 and reduced $3{ }^{\circ} \mathrm{C}$ each week until $24^{\circ} \mathrm{C}$ was reached.

Birds were fed the experimental diets (in mash form) formulated to supply the NRC (1994) recommendations for all nutrients except for NPP. A two-phase feeding program was applied: starter diets from 1 to $21 \mathrm{~d}$ and grower diets from 22 to $42 \mathrm{~d}$. The compositions of the starter and grower experimental diets are shown in Table 1. Basal diets, based on corn and soybean meal, were formulated and the treatment diets were obtained by supplementing the basal diets with monocalcium
Table 1 - Composition and nutritional levels of phosphorusdeficient basal diets

\begin{tabular}{|c|c|c|c|c|}
\hline \multirow[b]{2}{*}{ Ingredient (\%) } & \multicolumn{2}{|c|}{ Starter } & \multicolumn{2}{|c|}{ Grower } \\
\hline & Diet 1 & Diet 2 & Diet 1 & Diet 2 \\
\hline Ground yellow corn & 59.64 & 60.18 & 63.20 & 63.43 \\
\hline Soybean meal (dehulled) & 29.20 & 29.10 & 25.27 & 25.68 \\
\hline Puffing soybean & 3.00 & 3.00 & 3.00 & 3.00 \\
\hline Corn Gluten Meal & 3.00 & 3.00 & 1.31 & 1.00 \\
\hline Soybean oil & 0.95 & 0.76 & 3.30 & 3.22 \\
\hline Dicalcium phosphate & 1.29 & 0.68 & 1.02 & 0.42 \\
\hline Limestone & 1.30 & 1.66 & 1.36 & 1.71 \\
\hline L-Lysine & 0.38 & 0.38 & 0.27 & 0.27 \\
\hline lodized sodium chloride & 0.27 & 0.27 & 0.27 & 0.27 \\
\hline DL-methionine & 0.21 & 0.21 & 0.23 & 0.23 \\
\hline Sodium Bicarbonate & 0.12 & 0.12 & 0.12 & 0.12 \\
\hline Choline chloride & 0.10 & 0.10 & 0.10 & 0.10 \\
\hline Threonine & 0.04 & 0.04 & 0.05 & 0.05 \\
\hline Mineral-vitamin premix ${ }^{1,2}$ & 0.50 & 0.50 & 0.50 & 0.50 \\
\hline \multicolumn{5}{|l|}{ Calculated composition ${ }^{3}$} \\
\hline ME(MJ/kg) & 12.10 & 12.10 & 12.70 & 12.70 \\
\hline $\mathrm{CP}, \%$ & 20.50 & 20.50 & 18.00 & 18.00 \\
\hline $\mathrm{Ca}, \%$ & 0.90 & 0.90 & 0.85 & 0.85 \\
\hline Total P, \% & 0.58 & 0.48 & 0.50 & 0.40 \\
\hline Non-phytate P, \% & 0.35 & 0.25 & 0.30 & 0.20 \\
\hline \multicolumn{5}{|l|}{ Determined composition } \\
\hline$C P, \%$ & 20.36 & 20.41 & 18.18 & 17.89 \\
\hline $\mathrm{Ca}, \%$ & 0.93 & 0.89 & 0.84 & 0.87 \\
\hline Total P, \% & 0.57 & 0.48 & 0.52 & 0.43 \\
\hline Non-phytate $\mathrm{P}, \%$ & 0.34 & 0.26 & 0.31 & 0.22 \\
\hline
\end{tabular}

${ }^{1}$ Mineral-vitamin premix provided the following (per kilogram of diet): thiaminmononitrate, $2.4 \mathrm{mg}$; nicotinic acid, 44mg; riboflavin, $4.4 \mathrm{mg}$; D-Ca pantothenate, 12

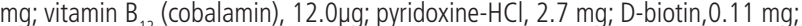
folic acid, $0.55 \mathrm{mg}$; vitamin A, $10000 \mathrm{IU}$; vitamin E,30IU; menadione sodium bisulfate complex, $3.34 \mathrm{mg}$; manganese, 120mg; iron, $100 \mathrm{mg}$; zinc, $100 \mathrm{mg}$; copper, $8 \mathrm{mg}$; iodine, $0.7 \mathrm{mg}$; selenium, $0.3 \mathrm{mg}$

2Vitamin $\mathrm{D}_{3}$ was removed from the vitamin mixture.

${ }^{3}$ Based on the tables of feed composition of NRC(1994).

phosphate, limestone, PHY (Natuphos, BASF), or 25$\mathrm{OH}-\mathrm{D}_{3}$ (DSM Nutritional Products). One unit (U) of phytase activity is defined as the amount of enzyme that releases $1 \mathrm{~mol}$ of inorganic $P$ from $1.5 \mathrm{mM} \mathrm{Na}$ phytate at $\mathrm{pH} 5.5$ and $37^{\circ} \mathrm{C}$. The birds in treatments 1-4 were fed with phosphorus deficient diet 1 (NPP level below NRC by 0.1 in each period), while the birds in treatments 5-8 were fed with phosphorus deficient diet 2 (NPP level below NRC by 0.2 in each period). The starter diets was formulated to contain $0.35 \%$ or $0.25 \%$ NPP and the grower diets were formulated to contain $0.3 \%$ or $0.25 \%$ NPP. Each phosphorusdeficient diet contained no Vitamin $\mathrm{D}_{3}$ and was mixed with $300 \mathrm{U} / \mathrm{kg}$ or $600 \mathrm{U} / \mathrm{kg}$ phytase and $34.5 \mu \mathrm{g} / \mathrm{kg}$ or $69 \mu \mathrm{g} / \mathrm{kg} 25-\mathrm{OH}-\mathrm{D}_{3}$. Two levels of NPP concentrations (NRC NPP reduced by 0.1 or 0.2 ), two levels of PHY $(300 \mathrm{U} / \mathrm{kg}$ or $600 \mathrm{U} / \mathrm{kg})$, and two levels of $25-\mathrm{OH}-\mathrm{D}_{3}$ $\left(34.5 \mu \mathrm{g} / \mathrm{kg}\right.$ diet or $69 \mu \mathrm{g} / \mathrm{kg}$ diet) resulted in a $2 \times 2 \times 2^{3}$ 
factorial design (NPP $\times$ PHY $\left.\times 25-O H-D_{3}\right)$, with a total of 8 experimental treatments (TRT), with 5 replicates (pens) per treatment (60 birds /pen). Normal level and lower level of phytase and $25-\mathrm{OH}-\mathrm{D}_{3}$ was included in the diets in attempt to allow for any potential additive or synergistic effects. Samples of all feeds were assayed for crude protein, calcium, and total phosphorus. Prior to mixing the diets, corn-25-OH- $\mathrm{D}_{3}$ premixes consisting of corn and an appropriate level of $25-\mathrm{OH}-\mathrm{D}_{3}$-premix were prepared and used in the basal diets.

The broiler house had a curtain with an ultraviolet inhibition during the study to prevent birds from being exposure to ultraviolet radiation. Feed and water were provided ad libitum during the experiment.

Mortality and leg abnormality of the birds were checked daily. Leg abnormality, including the deformed legs, valgus/varus, and tibial dyschondroplasia, was assessed by observing the walking ability (walking gait and speed) of the birds when moving spontaneously in the rearing environment. On d 21 and 42, two birds per pen were killed by cervical dislocation and their tibiae were removed to determine the presence or absence of physical leg abnormalities. Feed and broilers were weighed on $\mathrm{d} 21$ and 42 for the determination of body weight gain (BWG), feed intake (FI), and feed conversion ratio (FCR).

\section{Meat Quality Measurement}

At $d 42$, two birds per pen were killed by cervical dislocation and their right breast and thigh muscle were removed for $\mathrm{pH}$, color, and shear force determination. According to the method of Lu et al. (2006), at 45min postmortem, the $\mathrm{pH}$ of the breast and thigh muscles were tested with a pH meter (PHS-3C, Shanghai Precision and Scientific Instrument Co. Ltd., Shanghai, China). At $24 \mathrm{~h}$ postmortem, lightness $\left(L^{*}\right)$, redness $\left(a^{*}\right)$, and yellowness $\left(b^{*}\right)$ values of the muscles were measured using a WSC-S Chroma Meter (Shanghai Precision and Scientific Instrument Co. Ltd.). According to the procedure described by Honikel (1998), shear force of the breast and thigh raw meat was measured by using a C-LM3 Digital Meat Tenderness Meter (Northeast Agricultural University, Harbin, China).

\section{Statistical Analysis}

Replicate means served as the experimental unit for statistical analysis. Analysis of variance was performed on all data for the experiment using the GLM procedure of SAS (SAS Institute, 2001) appropriate for a randomized block design. Treatment means were compared using Duncan's multiple range test (Duncan, 1955). P-values lower than 0.05 or 0.01 indicate statistical significance.

\section{RESULTS}

\section{Body weight, survival rate, and leg abnor- mality rate}

The survival rate of broilers in all treatments was high, of more than $99 \%$, during the experimental periods, although NRC NPP was reduced by 0.2 . No leg abnormality was observed during starter phase and grower phase of the experiment (Table 2). The $21 \mathrm{~d}$ BW of chicks on TRT 1-4 (fed with $0.35 \%$ NPP diet) was higher than that of chicks on TRT 5-8 (fed

Table 2 - Effect of the combination of NPP, phytase and 25-OH-D3 on BW, mortality rate and leg abnormality rate of broilers

\begin{tabular}{|c|c|c|c|c|c|c|c|c|c|}
\hline \multirow[b]{2}{*}{ TRT } & \multirow[b]{2}{*}{ NPP1 } & \multirow[b]{2}{*}{ Phytase $^{2}$} & \multirow[b]{2}{*}{$25-\mathrm{OH}-\mathrm{D}_{3}{ }^{3}$} & \multicolumn{3}{|c|}{$1-21 d$} & \multicolumn{3}{|c|}{$22-42 d$} \\
\hline & & & & $21 \mathrm{~d} \mathrm{BW}^{4}$ & $\begin{array}{l}\text { Survival } \\
\text { rate }\end{array}$ & $\begin{array}{l}\text { Leg } \\
\text { abnormality } \\
\text { rate }\end{array}$ & 42d BW & $\begin{array}{l}\text { Survival } \\
\text { rate }\end{array}$ & $\begin{array}{c}\text { Leg } \\
\text { abnormality } \\
\text { rate }\end{array}$ \\
\hline & $(\%)$ & (U/kg) & $(\mu \mathrm{g} / \mathrm{kg})$ & (g/bird) & $(\%)$ & $(\%)$ & (g/bird) & $(\%)$ & $(\%)$ \\
\hline 1 & 0.35 & 300 & 34.5 & $360.2 \pm 2.87^{b}$ & 99.33 & 0 & $979.6 \pm 12.6^{a b c}$ & 100 & 0 \\
\hline 2 & 0.35 & 300 & 69 & $358.6 \pm 4.67^{b}$ & 99.33 & 0 & $989.4 \pm 9.2^{\mathrm{abc}}$ & 100 & 0 \\
\hline 3 & 0.35 & 600 & 34.5 & $368.4 \pm 3.04^{a}$ & 99.00 & 0 & $1007.8 \pm 9.02^{\mathrm{a}}$ & 100 & 0 \\
\hline 4 & 0.35 & 600 & 69 & $371.8 \pm 2.63^{a}$ & 99.67 & 0 & $999.2 \pm 17.0^{\mathrm{ab}}$ & 100 & 0 \\
\hline 5 & 0.25 & 300 & 34.5 & $345.8 \pm 3.73^{c}$ & 99.67 & 0 & $952.2 \pm 14.2^{c}$ & 100 & 0 \\
\hline 6 & 0.25 & 300 & 69 & $343.4 \pm 4.79^{c}$ & 99.33 & 0 & $959.2 \pm 15.3^{b c}$ & 99.64 & 0 \\
\hline 7 & 0.25 & 600 & 34.5 & $338.4 \pm 2.06^{c}$ & 100 & 0 & $962.4 \pm 10.3^{b c}$ & 100 & 0 \\
\hline 8 & 0.25 & 600 & 69 & $333.2 \pm 5.77 c$ & 99.33 & 0 & $968.0 \pm 11.5^{\mathrm{abc}}$ & 100 & 0 \\
\hline
\end{tabular}

a-c Means with no common superscripts in the same column significantly differ $(p \leq 0.05)$.

1. NPP =non-phytate P. From 1 to $21 \mathrm{~d}$, NPP levels for broilers on treatment $1-4$ and treatment $5-8$ were $0.35 \%$ and $0.25 \%$, respectively. From 22 to $42 \mathrm{~d}$, NPP levels for broilers on treatment $1-4$ and treatment $5-8$ were $0.3 \%$ and $0.2 \%$ respectively.

2. Natuphos, BASF, $1 \mathrm{U}$ of PHY is defined as the amount of enzyme required to liberate $1 \mathrm{~mol}$ of inorganic $\mathrm{P}$ from $1.5 \mathrm{mM} \mathrm{Na}$ phytate at pH 5.5 and $37^{\circ} \mathrm{C}$

3. 25-OH-D $3=25$-hydroxycholecalciferol, Hy-D, DSM Vitamins, Shanghai,Ltd, $69 \mu \mathrm{g} / \mathrm{kg}$ diet=2,760 IU/kg diet.

4. Means represent five pens of sixty birds each, $n=5$, Average initial weight of the chicks was $35.2 \mathrm{~g}$. 
with $0.25 \%$ NPP diet). The broilers on TRT 4 (fed with $0.35 \% \mathrm{NPP}$ diet $+600 \mathrm{U} / \mathrm{kg}$ phytase $+69 \mu \mathrm{g} / \mathrm{kg} 25-\mathrm{OH}-$ $\mathrm{D}_{3}$ ) grew better than those on any other TRT during starter phase. The BW of chicks on TRT 4 was $11.2 \%$ higher $(p<0.05)$ than that of chicks on TRT 8 at $d 21$. The broilers on TRT 3 (fed with $0.30 \%$ NPP diet +600 $\mathrm{U} / \mathrm{kg}$ phytase $\left.+34.5 \mu \mathrm{g} / \mathrm{kg} 25-\mathrm{OH}-\mathrm{D}_{3}\right)$ grew better $(\mathrm{p}<$ $0.05)$ than those on any other TRT at $d 42$. The BW of chicks on TRT 3 was $5.84 \%$ higher $(p<0.05)$ than that of chicks on TRT 5 at $d 42$.

\section{Starter Phase (Hatch to 21 d of Age) Per- formance}

The greatest BWG was obtained by broilers on TRT 4 (fed with $0.35 \%$ NPP diet + 600U $/ \mathrm{kg}$ phytase + $69 \mu \mathrm{g} / \mathrm{kg} 25-\mathrm{OH}-\mathrm{D}_{3}$ ) in the starter phase (Table 3). FCR of chicks on TRT 4 (fed with $0.35 \%$ NPP diet $+600 \mathrm{U} /$ $\mathrm{kg}$ phytase $+69 \mu \mathrm{g} / \mathrm{kg} 25-\mathrm{OH}-\mathrm{D}_{3}$ ) and TRT 3 (fed with $0.35 \%$ NPP diet $+600 \mathrm{U} / \mathrm{kg}$ phytase $+34.5 \mu \mathrm{g} / \mathrm{kg} 25-$ $\left.\mathrm{OH}-\mathrm{D}_{3}\right)$ was significantly lower $(\mathrm{p}<0.05)$ than that on any other TRT. The BWG and feed intake of chicks on TRT 1-4 (fed with 0.35\% NPP diet) was significantly higher $(p<0.05)$ by $7.87 \%$ and $6.36 \%$ than that of chicks on TRT $5-8$ (fed with $0.25 \%$ NPP diet). FCR of chicks on TRT 1-4 (fed with $0.35 \%$ NPP diet) was significantly lower $(p<0.05)$ than that of chicks on TRT 5-8 (fed with 0.25\% NPP diet). The BWG, feed intake, and FCR were not influenced by different phytase or 25-OH-D levels.

\section{Grower Phase (22 to 42 d of age) Perfor- mance}

In the grower phase, the BWG and FCR of chicks were not affected when NRC NPP was reduced by 0.1

Table 3 - Effect of the combination of NPP, phytase and 25-OH-D on the performance of starter broilers (1 to 21 days).

\begin{tabular}{|c|c|c|c|c|c|c|}
\hline TRT & $\begin{array}{l}\mathrm{NPP}^{1} \\
(\%)\end{array}$ & $\begin{array}{c}\text { Phytase }^{2} \\
(\mathrm{U} / \mathrm{kg})\end{array}$ & $\begin{array}{c}25-\mathrm{OH}-\mathrm{D}_{3}{ }^{3} \\
(\mu \mathrm{g} / \mathrm{kg})\end{array}$ & $\begin{array}{c}\mathrm{BWG}^{4} \\
(\mathrm{~g})\end{array}$ & $\begin{array}{l}\text { Feed intake } \\
\text { (g) }\end{array}$ & $\begin{array}{l}\text { FCR } \\
(g / g)\end{array}$ \\
\hline 1 & 0.35 & 300 & 34.5 & $325^{a b}$ & $547^{a}$ & $1.68^{a b}$ \\
\hline 2 & 0.35 & 300 & 69 & $323^{b}$ & $545^{a}$ & $1.69^{a}$ \\
\hline 3 & 0.35 & 600 & 34.5 & $333^{\mathrm{ab}}$ & $557^{a}$ & $1.67^{b}$ \\
\hline 4 & 0.35 & 600 & 69 & $336^{a}$ & $558^{a}$ & $1.66^{b}$ \\
\hline 5 & 0.25 & 300 & 34.5 & $310^{c}$ & $527^{b}$ & $1.70^{a}$ \\
\hline 6 & 0.25 & 300 & 69 & $308^{c}$ & $524^{b}$ & $1.70^{\mathrm{a}}$ \\
\hline 7 & 0.25 & 600 & 34.5 & $303^{c}$ & $515^{b c}$ & $1.70^{\mathrm{a}}$ \\
\hline 8 & 0.25 & 600 & 69 & $298^{c}$ & $509 c$ & $1.71^{\mathrm{a}}$ \\
\hline SEM $^{5}$ & & & & 4.12 & 5.06 & 0.011 \\
\hline$P$ & & & & $<0.0001$ & $<0.0001$ & 0.0146 \\
\hline \multicolumn{7}{|l|}{ NPP effect } \\
\hline 0.35 & & & & $329^{a}$ & $552^{a}$ & $1.68^{b}$ \\
\hline 0.25 & & & & $305^{b}$ & $519^{b}$ & $1.70^{a}$ \\
\hline \multicolumn{7}{|l|}{ Phytase effect } \\
\hline 300 & & & & 317 & 536 & 1.70 \\
\hline 600 & & & & 318 & 535 & 1.69 \\
\hline \multicolumn{7}{|l|}{$25-\mathrm{OH}-\mathrm{D}_{3}$ effect } \\
\hline 34.5 & & & & 318 & 537 & 1.69 \\
\hline 69 & & & & 316 & 534 & 1.69 \\
\hline \multicolumn{7}{|l|}{ Source of Variation } \\
\hline NPP & & & & 0.0001 & 0.0001 & 0.0087 \\
\hline Phytase & & & & 0.662 & 0.790 & 0.234 \\
\hline $25-\mathrm{OH}-\mathrm{D}_{3}$ & & & & 0.560 & 0.427 & 0.458 \\
\hline NPP $\times$ Phytase & & & & 0.0019 & 0.0012 & 0.233 \\
\hline Phytase $\times 25-\mathrm{OH}-\mathrm{D}_{3}$ & & & & 0.942 & 0.976 & 0.958 \\
\hline $\mathrm{NPP} \times 25-\mathrm{OH}-\mathrm{D}_{3}$ & & & & 0.467 & 0.536 & 0.566 \\
\hline NPP $\times$ Phytase $\times 25-O H-D_{3}$ & & & & 0.513 & 0.658 & 0.638 \\
\hline
\end{tabular}

a-c Means with no common superscripts in the same column significantly differ $(p \leq 0.05)$.

1. NPP = non-phytate $P$

2. Natuphos, BASF

3. $25-\mathrm{OH}-\mathrm{D}_{3}=25$-hydroxycholecalciferol, Hy-D, DSM Vitamins, shanghai, Ltd, $69 \mu \mathrm{g} / \mathrm{kg}$ diet=2,760 IU $/ \mathrm{kg}$ diet.

4. Means represent five pens of sixty birds each, $n=5$, Average initial weight of the chicks was $35.2 \mathrm{~g} ; \mathrm{BWG}=$ body weight gain; $F C R=f e e d$ conversion ratio.

5. Weighted average of the SEM 
to 0.2 , but feed intake decreased by 2.67\%(from 1461 $\mathrm{g} / \mathrm{bird} / \mathrm{d}$ to $1422 \mathrm{~g} / \mathrm{bird} / \mathrm{d}$ ) when NRC NPP was lowered by 0.1 to 0.2 (Table 4). The BWG, feed intake, and FCR of chicks were not influenced by different phytase or 25-OH-D levels.

\section{Cumulative (Hatch to $42 \mathrm{~d}$ of age) Perfor- mance}

The broilers on TRT 3 (NRC NPP reduced by $0.1+$ $600 \mathrm{U} / \mathrm{kg}$ phytase $+34.5 \mu \mathrm{g} / \mathrm{kg} 25-\mathrm{OH}-\mathrm{D}_{3}$ ) and TRT 4 (NRC NPP reduced by $0.1+600 \mathrm{U} / \mathrm{kg}$ phytase $+69 \mu \mathrm{g} /$ $\mathrm{kg} 25-\mathrm{OH}-\mathrm{D}_{3}$ ) grew better and ate more than those on any other TRT (Table 5). The BWG and feed intake of chicks on TRT 3 and TRT 4 were $973 \mathrm{~g}$ and $2038 \mathrm{~g}$, and $964 \mathrm{~g}$ and $2021 \mathrm{~g}$, respectively. The lowest BWG (917g) and feed intake (1930g) were observed in TRT 5 (NRC
NPP reduced by $0.2+300 U / \mathrm{kg}$ phytase $+34.5 \mu \mathrm{g} / \mathrm{kg}$ $25-\mathrm{OH}-\mathrm{D}_{3}$ ). The BWG was $6.11 \%$ and $5.13 \%$ higher $(p<0.05)$ in birds on TRT 3 and TRT 4, respectively, compared with those on TRT 5.

The BWG and feed intake of chicks on TRT 1-4 (NRC NPP reduced by 0.1 plus phytase and $25-\mathrm{OH}-\mathrm{D}_{3}$ ) was significantly greater $(p<0.05)$ by $3.68 \%$ and $3.71 \%$, respectively, compared with TRT 5-8 (NRC NPP reduced by 0.2 plus phytase and $25-\mathrm{OH}-\mathrm{D}_{3}$ ) from 1 to $42 \mathrm{~d}$. No significant differences ( $p>0.05$ ) were found in FCR of chicks from 1 to $42 \mathrm{~d}$ in any of TRT.

\section{Meat Quality}

There was no significant difference in the lightness ( $L$ * value; $p=0.583$ ), redness ( $a *$ value; $p=0.273$ ), yellowness ( $b *$ value; $p=0.296), p H(p=0.878)$, or shear

Table 4 - Effect of the combination of NPP, phytase and 25-OH-D 3 on the performance of grower broilers (22 to 42 days).

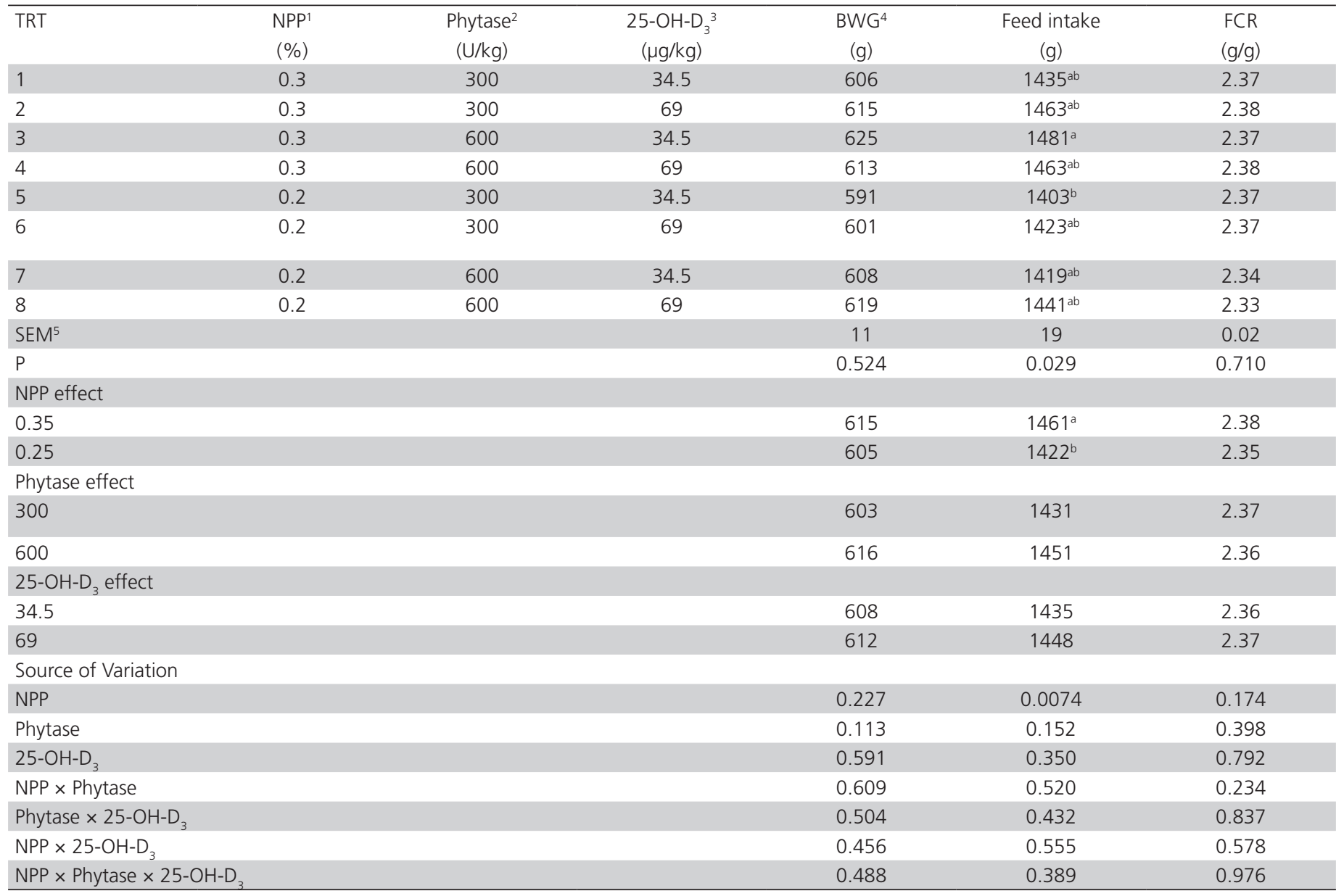

a-c Means with no common superscripts in the same column significantly differ $(p \leq 0.05)$.

1. NPP =non-phytate $P$

2. Natuphos, BASF

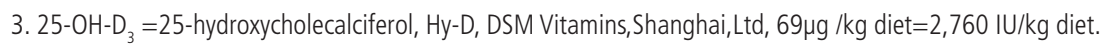

4. Means represent five pens of sixty birds each, $n=5 ; B W G=$ body weight gain; $F C R=$ feed conversion ratio.

5. Weighted average of the SEM 
Table 5 - Effect of the combination of NPP, phytase and 25-OH- $\mathrm{D}_{3}$ on the performance of 1- to 42-d-old broilers

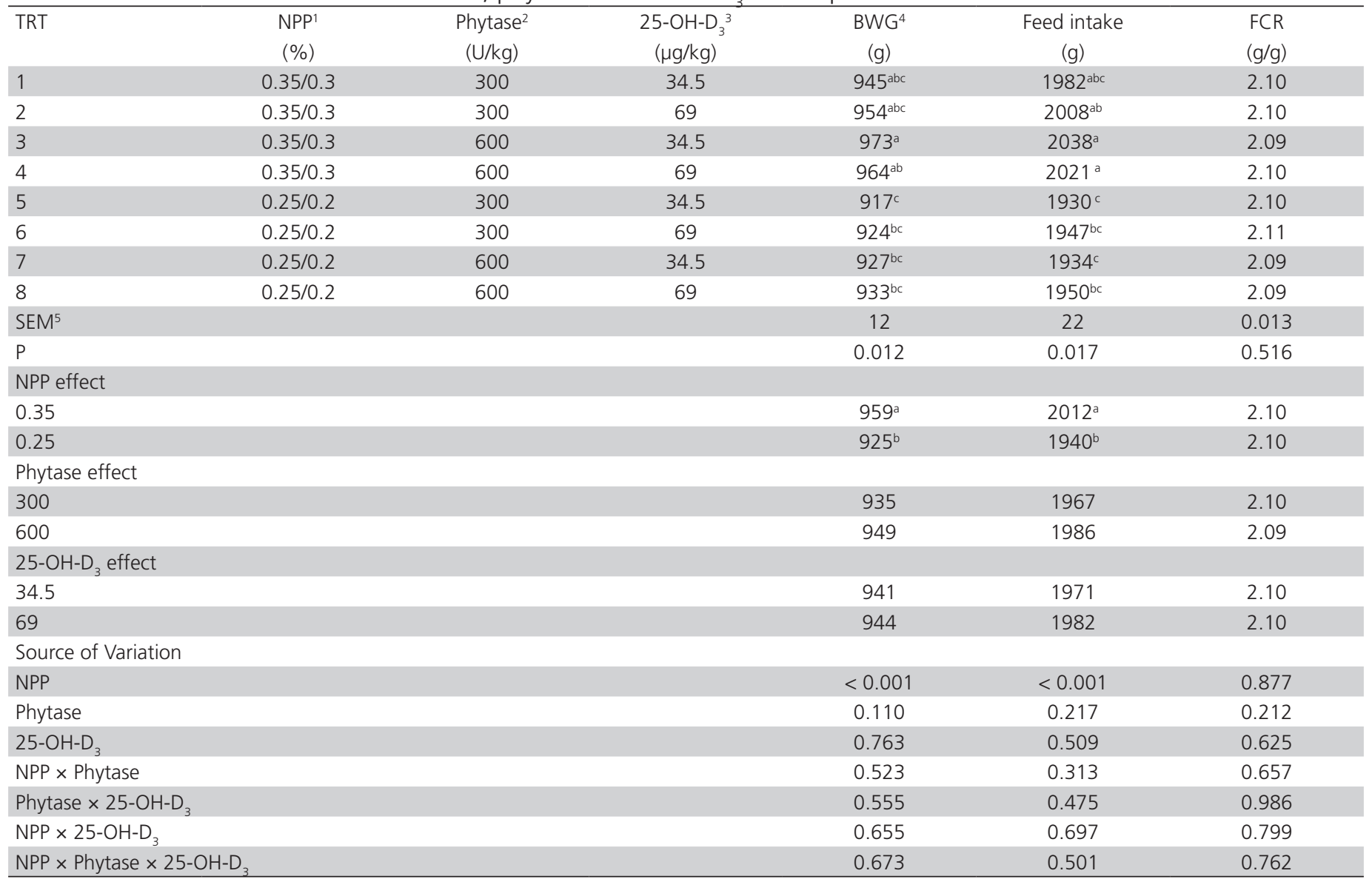

acc Means with no common superscripts in the same column significantly differ $(\mathrm{p} \leq 0.05)$.

1. NPP =non-phytate P. From 1 to $21 \mathrm{~d}$, NPP levels for broilers on treatment $1-4$ and treatment $5-8$ were $0.35 \%$ and $0.25 \%$ respectively. From 22 to $42 \mathrm{~d}$, NPP levels for broilers on treatment $1-4$ and treatment $5-8$ were $0.3 \%$ and $0.2 \%$ respectively.

2. Natuphos, BASF

3. 25-OH-D $=25$-hydroxycholecalciferol, Hy-D, DSM Vitamins, shanghai,Ltd, $69 \mu \mathrm{gg} / \mathrm{kg}$ diet=2,760 IU/kg diet.

4. Means represent five pens of sixty birds each, $n=5$, Average initial weight of the chicks was $35.2 \mathrm{~g} ; B W G=$ body weight gain; $F C R=$ feed conversion ratio.

5. Weighted average of the SEM

force $(p=0.142)$ of breast meat among TRT (Table 6). The lightness ( $L^{*}$ value), redness ( $a^{*}$ value), yellowness ( $b^{*}$ value), $\mathrm{pH}$, and shear force of breast meat were not affected by different NPP, phytase, or 25-OH-D levels.

Results (Table 7) showed that no significant difference was observed in the lightness ( $L^{*}$ value; $p=0.296$ ), redness ( $a^{*}$ value; $p=0.421$ ), yellowness ( $b$ * value; $P=0.205), p H(p=0.527)$, or shear force $(p=0.454)$ of thigh meat among treatments. The lightness ( $L^{*}$ value), redness ( $a *$ value), yellowness ( $b$ * value), $\mathrm{pH}$, and shear force of thigh meat were not affected by different NPP, phytase or $25-\mathrm{OH}-\mathrm{D}_{3}$ levels.

\section{DISCUSSION}

\section{Growth Performance}

The current NPP recommendation for broilers is $0.45 \%$ from 1 to $21 \mathrm{~d}$ of age and $0.35 \%$ from 22 to $42 \mathrm{~d}$ of age. In this study, the level of dietary NPP was 0.1 and 0.2 below the NRC (1994) when phytase and $25-\mathrm{OH}-\mathrm{D}_{3}$ were added in each period to spare NPP. Under this situation, no leg abnormality and deleterious effects on survival rate were observed. This is consistent with the findings of Coto et al. (2008), who reported that there were no negative effects on performance of feeding a phosphorus-deficient diet with the addition of phytase and $25-\mathrm{OH}-\mathrm{D}_{3}$. Similarly, Biehl et al. (1995) reported that the correct combination of phytase and $1 \alpha-\mathrm{OH}-\mathrm{D}_{3}$ could substantially reduce the required level of inorganic $P$ supplementation, and consequently reduce the $\mathrm{P}$ level in excreta. Yan et al. (2003) suggested that the NPP requirement for optimal tibia ash content was $0.15 \pm 0.049 \%$ at $49 d$, when diets were supplemented with phytase.

During the entire experiment, lowering NRC NPP by 0.1 to 0.2 with the addition of phytase and 25- 
Table 6 - Effect of the combination of NPP, phytase and $25-\mathrm{OH}-\mathrm{D}_{3}$ on breast meat quality of 42 -d-old broilers

\begin{tabular}{|c|c|c|c|c|c|c|c|c|}
\hline TRT & $\begin{array}{l}\mathrm{NPP}^{1} \\
(\%)\end{array}$ & $\begin{array}{l}\text { Phytase }^{2} \\
(\mathrm{U} / \mathrm{kg})\end{array}$ & $\begin{array}{c}25-\mathrm{OH}-\mathrm{D}_{3}{ }^{3} \\
(\mu \mathrm{g} / \mathrm{kg})\end{array}$ & $\begin{array}{c}\mathrm{L}^{*} \text { value } \\
\text { (lightness) }\end{array}$ & $\begin{array}{l}a^{*} \text { value } \\
\text { (redness) }\end{array}$ & $\begin{array}{c}\text { b* value } \\
\text { (yellowness) }\end{array}$ & $\mathrm{pH}$ & $\begin{array}{c}\text { Shear force } \\
\text { (N) }\end{array}$ \\
\hline 1 & 0.3 & 300 & 34.5 & 52.60 & 15.40 & 9.52 & 6.04 & 13.18 \\
\hline 2 & 0.3 & 300 & 69 & 51.72 & 16.60 & 9.44 & 6.05 & 13.17 \\
\hline 3 & 0.3 & 600 & 34.5 & 51.88 & 16.95 & 9.72 & 6.04 & 13.20 \\
\hline 4 & 0.3 & 600 & 69 & 53.06 & 15.65 & 8.74 & 6.02 & 13.23 \\
\hline 5 & 0.2 & 300 & 34.5 & 52.13 & 16.53 & 9.59 & 6.02 & 13.21 \\
\hline 6 & 0.2 & 300 & 69 & 51.39 & 16.76 & 8.61 & 6.03 & 13.19 \\
\hline 7 & 0.2 & 600 & 34.5 & 51.69 & 16.36 & 9.54 & 6.04 & 13.15 \\
\hline 8 & 0.2 & 600 & 69 & 52.04 & 16.11 & 9.23 & 6.04 & 13.18 \\
\hline SEM $^{5}$ & & & & 1.18 & 0.83 & 0.42 & 0.05 & 0.08 \\
\hline P & & & & 0.583 & 0.273 & 0.296 & 0.878 & 0.142 \\
\hline \multicolumn{9}{|c|}{ NPP effect } \\
\hline 0.35 & & & & 52.32 & 16.15 & 9.35 & 6.04 & 13.20 \\
\hline 0.25 & & & & 51.82 & 16.44 & 9.24 & 6.03 & 13.18 \\
\hline \multicolumn{9}{|c|}{ Phytase effect } \\
\hline 300 & & & & 51.96 & 16.33 & 9.29 & 6.04 & 13.19 \\
\hline 600 & & & & 52.17 & 16.27 & 9.31 & 6.04 & 13.19 \\
\hline \multicolumn{9}{|c|}{$25-\mathrm{OH}-\mathrm{D}_{3}$ effect } \\
\hline 34.5 & & & & 52.08 & 16.31 & 9.59 & 6.04 & 13.19 \\
\hline 69 & & & & 52.06 & 16.28 & 9.01 & 6.04 & 13.19 \\
\hline \multicolumn{9}{|c|}{ Source of Variation } \\
\hline NPP & & & & 0.210 & 0.402 & 0.518 & 0.553 & 0.571 \\
\hline Phyta & & & & 0.939 & 0.871 & 0.669 & 0.572 & 0.219 \\
\hline $25-\mathrm{O}$ & & & & 0.651 & 0.927 & 0.146 & 0.530 & 0.326 \\
\hline NPP $\times$ & & & & 0.806 & 0.299 & 0.359 & 0.774 & 0.716 \\
\hline Phyta & & & & 0.084 & 0.134 & 0.718 & 0.340 & 0.079 \\
\hline NPP $\times$ & & & & 0.896 & 0.950 & 0.717 & 0.384 & 0.248 \\
\hline NPP $\times$ & $\mathrm{H}-\mathrm{D}_{3}$ & & & 0.408 & 0.147 & 0.833 & 0.676 & 0.187 \\
\hline
\end{tabular}

a-c Means with no common superscripts in the same column significantly differ $(p \leq 0.05)$.

1. NPP =non-phytate $P$

2. Natuphos, BASF

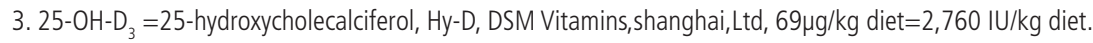

4. Means represent five pens of sixty birds each, $n=5$.

5. Weighted average of the SEM

$\mathrm{OH}-\mathrm{D}_{3}$ reduced BWG and feed intake of chicks. This result is consistent with previous reports (Angel et al., 2000 a,b; Karimi et al., 2013) indicating that lowering dietary NPP decreased the BWG and feed intake.

In this experiment, BWG and feed intake of starter chicks on TRT $1-4$ (fed with $0.35 \%$ NPP diet) was higher by $7.87 \%$ and $6.36 \%$ than that of chicks on TRT 5-8 (fed with $0.25 \%$ NPP diet), while the BWG and FCR of grower chicks on TRT 1-4 were similar to that on TRT 5-8. This indicated that reducing NRC NPP by 0.1 to 0.2 has a stronger effect on broiler performance more during the starter phase than during the grower phase. This result is consistent with the findings of Yan et al. (2005), who studied the ability of broiler chickens to adapt to early moderate $P$ deficiencies. Yan et al. (2005) found that broiler chickens fed a low NPP diet weighed less $(p<0.05)$ than those fed a control diet at $18 \mathrm{~d}$; however, by $23 \mathrm{~d}$, these broilers had caught up with the control birds, and no BW differences ( $p>$ 0.05 ) were observed on $d 28$ and 32. Hence, the author inferred that modern broilers have capacity to adapt when exposed to dietary $P$ restrictions.

The information obtained in this study indicated that BWG, feed intake, and FCR were not influenced by the different phytase or $25-\mathrm{OH}-\mathrm{D}_{3}$ levels. This corroborates the findings of Ana et al. (2013), who reported that the supplementation of the basal diet with $25-\mathrm{OH}-\mathrm{D}_{3}$ had no effect on BW. Additionally, Angel \& Mitchell (2006) reported that feeding diets low in phosphorus together with phytase and $25-\mathrm{OH}-$ $\mathrm{D}_{3}$ did not affect broiler performance. However, our results are contrary to those reported by Keshavarz (2003), Snow et al. (2004), and Emami et al. (2013), indicating that phytase addition increased ADG and ADFI in diets deficient in NPP. 
Table 7 - Effect of the combination of NPP, phytase and 25-OH-D3 on thigh meat quality of 42-d-old broilers

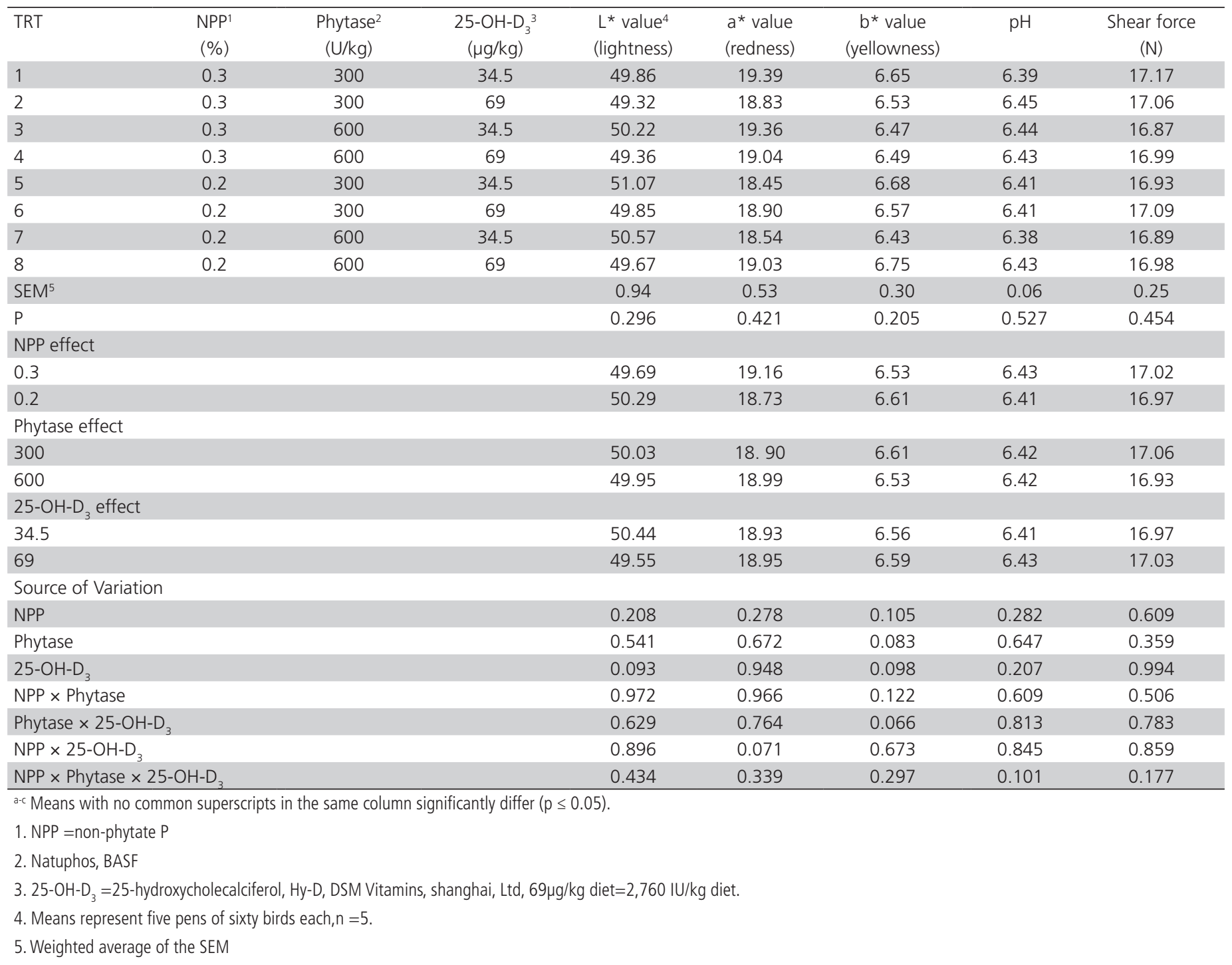

\section{Meat Quality}

There are no reports on the combined effects of NPP, $\mathrm{PHY}$, and $25-\mathrm{OH}-\mathrm{D}_{3}$ on the meat quality of broilers. More studies previously reported that the supplementation with vitamin $D_{3}$ before slaughter to cattle improved meat color (Wilborn et al., 2004;Lobo et al., 2012), decreased shear force (Tipton et al., 2007; Moron et al., 2008). Another study indicated that supplementation with vitamin $D_{3}$ improved steak tenderness by affecting muscle $\mathrm{Ca}$ concentrations, $\mu$-calpain activities, and muscle proteolysis (Montgomery et al., 2004).

Some paper reported the effect of $25-\mathrm{OH}-\mathrm{D}_{3}$ on meat quality. Lawrence et al. (2006) and Carnagey et al. (2008) reported that the supply of an oral bolus of $25-\mathrm{OH}-\mathrm{D}_{3}$ to cows before slaughter influenced some muscle characteristics known to enhance beef tenderness, despite no effect on tenderness was not observed. Cho et al. (2006) studied the effects of 25-hydroxy-vitamin $\mathrm{D}_{3}\left(25-\mathrm{OH}-\mathrm{D}_{3}\right)$ on carcass traits and beef tenderness and observed that, although Ca concentrations of the lean muscle numerically increased in response to $25-\mathrm{OH}-\mathrm{D}_{3}$ supplementation, no statistical differences in Warner-Bratzler shear force or sensory traits were detected. In the present experiment, lightness ( $L^{*}$ value), redness ( $a^{*}$ value), yellowness ( $b^{*}$ value), $\mathrm{pH}$, and shear force of thigh meat were not affected by different NPP, phytase, or $25-\mathrm{OH}-\mathrm{D}_{3}$ levels. This result is consistent with those mentioned above.

The different effects of $25-\mathrm{OH}-\mathrm{D}_{3}$ and vitamin $\mathrm{D}_{3}$ on meat quality are probably due differences in supplementation route, supplemental dose, animal type, etc. In most studies, vitamin $D_{3}$ was orally supplemented before slaughter and the experimental animals were cattle, whereas in the present study, 
$25-\mathrm{OH}-\mathrm{D}_{3}$ was supplemented in the diet from the beginning to the end of the experiment and the experimental animals were broilers. Hence, further investigations on these factors are needed.

\section{CONCLUSION}

1. During the entire experimental period, lowering NRC NPP by 0.2 and adding phytase and $25-\mathrm{OH}-\mathrm{D}_{3}$ did not affect the survival rate of broilers or caused leg abnormalities.

2. In the starter phase, reducing NRC NPP by 0.1 to 0.2 with the addition of phytase and $25-\mathrm{OH}-\mathrm{D}_{3}$ reduced broiler BWG and feed intake. In the grower phase, reducing NRC NPP by 0.1 to 0.2 and adding phytase and $25-\mathrm{OH}-\mathrm{D}_{3}$ to the diet did not affect BWG or FCR, produced a small decrease in feed intake of broilers.

3. Different levels of NPP, phytase, or 25-OH-D did not have significant effects on meat color, $\mathrm{pH}$, or shear force.

\section{ACKNOWLEDGEMENTS}

This research was supported by Nature Science Foundation of China (Beijing,China; No.30901033).

\section{REFERENCES}

Angel R, Applegate TJ, Christman M. Effect of dietary non-phytate phosphorus (NPP) on performance and bone measurements in broilers fed on a four-phase feeding system [abstract]. Poultry Science 2000a;79(Suppl1): 21-22.

Angel R, Applegate TJ, Christman M, Mitchell AD. Effect of dietary nonphytate phosphorus (NPP) level on broiler performance and bone measurements in the starter and grower phase [abstract]. Poultry Science 2000b;79(Suppl 1):22.

Angel R, Saylor WW, Dhandu AS, Powers W, Applegate TJ. Effects of dietary phosphorus, phytase, and 25-hydroxycholecalciferol on performance of broiler chickens grown in floor pens. Poultry Science 2005; 84:10311044.

Angel R, Saylor WW, Mitchell AD, Powers W, Applegate TJ. Effect of dietary phosphorus, phytase, and 25-hydroxycholecalciferol on broiler chicken bone mineralization, litter phosphorus, and processing yields. Poultry Science 2006;85:1200-1211

AOAC - Association of Official Analytical Chemists. Official methods of analysis of the association of official analytical chemists. Arlington; 1990.

Biehl RR, Baker DH, Deluca HF. 1-Hydroxylated cholecalciferol compounds act additively with microbial phytase to improve phosphorus, zinc, and manganese utilization in chicks fed soy-based diets. Journal of Nutrition 1995;125:2407-2416.

Carnagey KM, Huff-Lonergan EJ, Lonergan SM, Trenkle A, Horst RL, Beitz DC. Use of 25-hydroxyvitamin D3 and dietary calcium to improve tenderness of beef from the round of beef cows. Journal of Animal Science 2008;86:1637- 1648

Cho YM, Choi H, Hwang IH, Kim YK, Myung KH. Effects of 25-hydroxyvitamin D3 and manipulated dietary cation-anion difference on the tenderness of beef from cull native Korean cows. Journal of Animal Science, 2006;84:1481-1488

Coto C, Yan F, Cerrate S, Wang Z, Sacakli P. Effects of dietary levels of calcium and non-phytate phosphorus in broiler starter diets on live performance, bone development and growth plate conditions in male chicks fed a wheat based diet. International Journal of Poultry Science 2008;2:101-109.

Driver JP, Pesti GM, Bakalli RI, Edwards HM Jr. Phytase and $1 \alpha$ Hydroxycholecalciferol supplementation of broiler chickens during the starting and growing/finishing phases. Poultry Science 2005;84:16161628.

Duncan DB. Multiple range and multiple-F tests. Biometrics 1955;11:1-42.

Emami NK, Naeini SZ, Ruiz-Feria CA. Growth performance, digestibility, immune response and intestinal morphology of male broilers fed phosphorus-deficient diets supplemented with microbial phytase and organic acids. Livestock Science 2013;157:506-513.

Garcia FQM, Murakami AE, Duarte CAD, Rojas ICO, Picoli KP, Pugotti MM. Use of vitamin D3 and its metabolites in broiler chicken feed on performance, bone parameters and meat quality. Asian- Australasian Journal of Animal Science 2013;26:408-415. (Corrigir no texto de Ana et al. 2013 na p. 11 para Garcia et al. 2013)

Han JC, Yang XD, Zhang T, Li H, Li WL, Zhang ZY, Yao JH. Effects of 1alphahydroxycholecalciferol on growth performance, parameters of tibia and plasma, meat quality, and type llb sodium phosphate cotransporter gene expression of one to twenty-one-day-old broilers. Poultry Science 2009;88:323-329

Honikel KO. Reference methods for the assessment of physical characteristics of meat. Meat Science 1998;49: 447-457.

Janocha A, Osek M, Klocek B. Effect of adding 25-hydroxycholecalciferol in plant diets with and without fish meal on rearing results and bones of broiler chickens. Annals of Animal Science 2009;9:415-423.

Karimi A, Coto C, Mussini F, Goodgame S, Lu C, Yuan J, Bedford MR, Waldroup PW. Interactions between phytase and xylanase enzymes in male broiler chicks fed phosphorus-deficient diets from 1 to 18 days of age. Poultry Science 2013;92:1818-1823.

Keshavarz K. A Comparison between Cholecalciferol and 25-OHcholecalciferol on performance and eggshell quality of hens fed different levels of calcium and phosphorus. Poultry Science 2003;82:1415-1422.

Lalpanmawia H, Elangovan AV, Sridhar M, Shet D, Ajith S, Pal DT. Efficacy of phytase on growth performance, nutrient utilization and bone mineralization in broiler chicken. Animal Feed Science and Technology 2014;6(192):81-89.

Lawrence RW, Doyle J , Elliott R, Loxton I, McMeniman JP, Norton BW, Reid DJ, Tume RW. The efficacy of a vitamin D3 metabolite for improving the myofibrillar tenderness of meat from Bos indicus cattle. Meat Science 2006;72:69-78

Liem A,Pesti GM, Atencio A, Edwards HM. Experimental approach to optimize phytate phosphorus utilization by broiler chickens by addition of supplements. Poultry Science 2009;88:1655-1665

Lobo AR, Delgado EF, Mourao GB ,Pedreira, ACMS, Berndt A, Demarchi JJAA. Interaction of dietary vitamin D-3 and sunlight exposure on B. indicus cattle: Animal performance, carcass traits, and meat quality. Livestock Science 2012;145:196-204. 
Lu L, Ji C, Luo XG, Liu B, Yu SX. The effect of supplemental manganese in broiler diets on abdominal fat deposition and meat quality. Animal Feed Science and Technology 2006;129: 49-59.

Montgomery JL, King MB, Gentry JG, Barham AR, Barham BL, Hilton GG, Blanton Jr JR, Horst RL, Galyean ML, Morrow Jr KJ, Wester DB, Miller MF. Supplemental vitamin D3 concentration and biological type of steers. II. Tenderness, quality, and residues of beef. Journal of Animal Science 2004;82:2092-2104

Moron FO, Araujo FO, Pietrosemoli S , Gutierrez J ,Machado L, Martinez J. Effect of Vitamin D3 Supplementation on Meat Quality in Grazing Bovine Crossbred. Revista Cientifica-Facultad de Ciencias Veterinarias 2008;18:692-698.

National Research Council. Nutrient requirements of Poultry. 9th rev.ed. Washington: National Academy Press; 1994.

Naves LD, Rodrigues PB, Bertechini AG, Correa AD, Oliveira DH, Oliveira EC, Duarte WF, Cunha MRR. Comparison of methodologies to quantify phytate phosphorus in diets containing phytase and excreta from broilers. Asian-Australasian Journal of Animal Sciences 2014,27:10031012.

Pillai UP, Manoharan V, Lisle A, Li X, Bryden W. Phytase supplemented poultry diets affect soluble phosphorus and nitrogen in manure and manureamended soil. Journal of Environmental Quality 2009;38:1700-1708.

Powell S, Johnston S, Gaston L, Southern LL. The effect of dietary phosphorus level and phytase supplementation on growth performance, bonebreaking strength, and litter phosphorus concentration in broilers. Poultry Science 2008;87:949-957.

Rama Rao SV, Raju MVLN, Panda AK, Shyam Sunder G, Sharma RP. Performance and bone mineralisation in broiler chicks fed on diets with different concentrations of cholecalciferol at a constant ratio of calcium to non-phytate phosphorus. British Poultry Science 2009;50:528-535.
SAS Institute. SAS user's guide. Version 8 ed. Cary; 2001.

Snow JL, Baker DH, Parsons CM. Phytase, citric acid, and 1alphahydroxycholecalciferol improve phytate phosphorus utilization in chicks fed a corn-soybean meal diet. Poultry Science 2004;83:1187-1192.

Summers JD. Precision phosphorus nutrition. Journal of Applied Poultry Science 1997;6:495-500

Tatara MR, Krupski W, Jankowski M, Zduńczykd Z, Jankowskic J, Studzińskie T. Effects of dietary calcium content and vitamin D source on skeletal properties in growing turkeys. British Poultry Science 2011;52:718729

Tipton NC, King DA, Paschal JC, Hale DS, Savell JW. Effects of oral vitamin D3 supplementation and supplement withdrawal on the accumulation of magnesium, calcium, and vitamin D in the serum, liver, and muscle tissue and subsequent carcass and meat quality of Bos indicus influenced cattle. Meat Science 2007;75:150-158.

Wilborn BS, Kerth CR, Owsley WF, Jones WR, Frobish LT. Improving pork quality by feeding supranutritional concentrations of vitamin D3. Journal of Animal Science, 2004;82: 218-224.

Yan F, Kersey JH, Waldroup PW. Phosphorus requirements of broiler chicks three to six weeks of age as influenced by phytase supplementation. Poultry Science 2001;80: 455-459.

Yan F, Kersey JH, Fritts CA, Waldroup PW. Phosphorus requirements of broiler chicks six to nine weeks of age as influenced by phytase supplementation. Poultry Science 2003;82: 294-300.

Yan F, Angel R, Ashwell C, Mitchell A, Christman M. Evaluation of the broiler's ability to adapt to an early moderate deficiency of phosphorus and calcium. Poultry Science 2005;84: 1232 -1241. 